\title{
A tradition-historical analysis of Psalm 55
}

D J Human

(UP)

\section{ABSTRACT}

\section{A tradition-historical analysis of Psalm 55}

The text of Psalm 55 will be remembered for its musical setting by Felix Mendelsohn and others and also for the fact that it is one of the most difficult psalms to analyse. A tradition-historical analysis of the traditions and history of the poem confirms the unique and independent character of the text. The content of the psalm is characterised by vague allusions to well-known salvational and historical traditions as well as the psalm's characteristic formulations. Themes from the primeval history and desert wanderings of Israel are identifiable. Moreover, terminology with a socalled priestly background, reflect the psalm's cultic setting and function, while a theme from the Zion tradition is also evident. Prophetic language is evident in both legal concepts and terminology which expresses guilt. Relationships with wisdom texts are also evident. This article is an attempt to identify and determine the function of the above-mentioned traditionsgeschichtliche themes in order to gain a better understanding of the text.

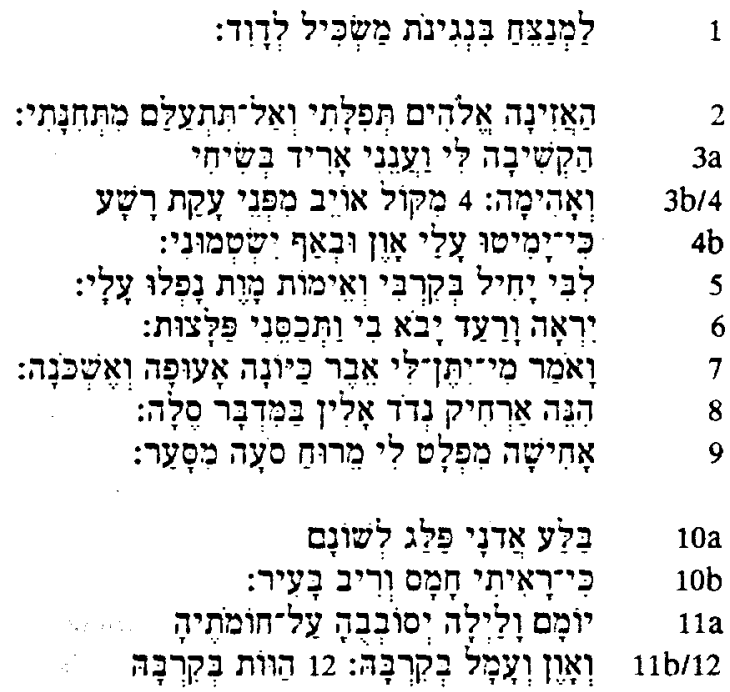




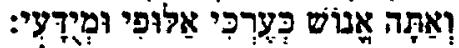

\begin{tabular}{|c|c|}
\hline סיצני: & \\
\hline 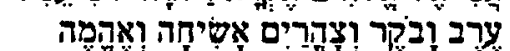 & 18 \\
\hline 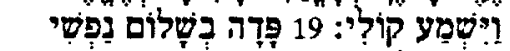 & $18 \mathrm{~b} / 19$ \\
\hline פִיקוּר & $19 b$ \\
\hline 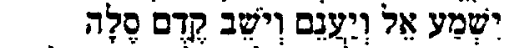 & 20 \\
\hline 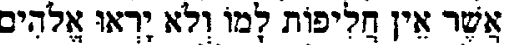 & $20 \mathrm{~b}$ \\
\hline 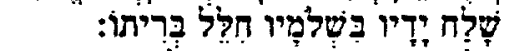 & 21 \\
\hline 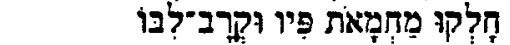 & $22 a$ \\
\hline 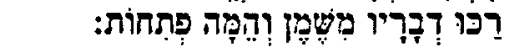 & $22 b$ \\
\hline 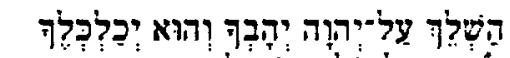 & 23 \\
\hline 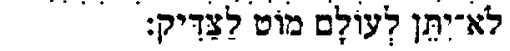 & $23 l$ \\
\hline 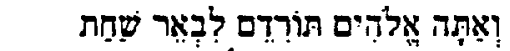 & $24 a$ \\
\hline 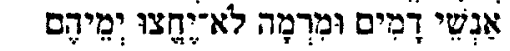 & $24 b$ \\
\hline & 246 \\
\hline
\end{tabular}

\section{INTRODUCTION}

Despite the complexity of Psalm 55 and the difficulty of interpreting it, which gained the poem the description of a "vielfach dunkles Gedicht"! this psalm provides the interpreter with the enjoyment of its several musical settings and the challenge of discovering the various dimersions of its meaning.

Being part of both the so-called Elohist (43-89) and the Davidic collection (51-70), the psalm is a description of the human experience in which the endangered and desolate " $I$ " finds comfort in the anticipation that God will respond to the appeal of the distressed righteous person. Due to this comfort the psalmist's trust in God steadily increases. What starts as a death experience accompanied by petitions, pleas and wishes to flee and find consolation in the desert (2-9), culminates steigerungsmäßig in hopeful utterances that God is taking care of the צדיק. The experience is ultimately crowned with the psalmist's confession of his solemn trust in God (24c). 
In terms of its Gattung, Psalm 55 is generally described by the exegetes as an individual lament ${ }^{2}$. This is a vague depiction, because the psalm contains various genre elements, each of which fulfills a unique function in the structure of the poem. There is therefore not sufficient justification to reduce the psalm to a description such as "an individual lament". It contains several form-critical elements, including petitions and prayer (2-3), descriptive complaints $(3 c-6,10 b-15 c, 21-22)$, wishes to flee (7-9), pleas and wishes for destruction $(10 \mathrm{a}, 16)$ elements of Gewißheit der Erhörung (17-22, 24ab), a hymnical theme (20a), promises of salvation and doom (23) and confession of trust (24c). These elements, each with its own function and emphasis, raise the question whether the complaint/lament or the prayer should be emphasised in the classification of the psalm's literary genre. Suggestions that it should be categorised as a "klaag- en bidpsalm"3, "prayer song"4, "Klagegebet"5, "complaint prayer"6, "Lied den Bittgebeten" 7 or simply a "prayer" 8 illustrate this dilemma. It is, however, unnecessary to choose between categorising the psalm as either a complaint/lament or a prayer, because the fusion of Gattung elements and the function of each element in the composition of the psalm renders any choice futile. The solution to the problem is to accept that categorisation is provisional and that the debate on the genre of the psalms should be revisited.

There have been three main issues in the research on Psalm 55 . They concern the textual and text critical problems; unity and composition of the psalm; and its historical setting, i e questions regarding its Sitz im Leben, date and author. These issues are interrelated to such an extent that it would be extremely difficult to consider them separately. Nevertheless, each of these areas deserves attention and could prove to be invaluable in the exposition of the psalm.

The issue of the unity and composition of the psalm as well as the problems regarding its Sitz im Leben have been addressed extensively in another context ${ }^{9}$. These issues will therefore not be repeated here. The aim of this article is to present an exposition of some traditionsgeschichtliche elements of the psalm and to identify the function of some traditionhistorical themes and allusions that appear in it in order to improve understanding of the text.

\section{STRUCTURE}

Despite the daunting problem of interpreting Psalm $55^{10}$, its text could be read as a logical unit, comprising four stanzas, namely: 

(1) - Heading
A (2-9) - Prayer for deliverance
B (10-16) - Prayer for the destruction of the enemy
C (17-22) - Confidence in God's faithfulness which contrasts with the enemy's unfaithfulness
D (23-24) - Encouragement and confirmation of the supplicant's trust in God.

In the first strophe (2-3b/4) of stanza A (2-9) the psalmist calls on God to intercede in his distressful situation which is caused by the wicked enemy. The next strophe (4b-6) continues to sketch the effect of this distress on his life. The prayer culminates in the wish to flee and find shelter in the desert, away from the danger (7-9). In stanza B (10-16) God is urged with a double plea (10) and a wish (16) to demolish the enemy. The psalmist supports his first supplication (10a) by raising both a social danger (10b12) and an experience that is private threatening (13-15b), while his wish in 16 is supported by a nominal clause stated in staccato format which illustrates the evil in the city centre. All three arguments in support $(10 \mathrm{~b}$, $13,16)$ are introduced by the causal indicator ' 2 . The tension caused by the distress is lifted and replaced in the first strophe of stanza C (17-22) by the notion of God's anticipated intervention. He will hear $(17 \ldots$ ymi) the psalmist's cry for help. Antithetically, the second strophe contains a colourful description of the enemy's unfaithful behaviour which contrasts with the faithfulness of God, who will also "hear" (20 ... yמש ) the enemy and react to his mischievous behaviour.

A number of imperatives introduce the encouragement which appears in stanza D (23-24). God's deliverance of the righteous, and condemnation of the "men of blood and fraud" is emphasised before, finally, confirmation of trust or confession of faith is expressed.

\section{TRADITIONS AND HISTORICAL SETTING}

\subsection{Introduction}

An tradition-historical analysis of Psalm 55 confirms the unique and independent character of the text. The text is characterised by vague allusions to and themes from well-known Old Testament traditions as well as Sonderforme and the psalmist's characteristic formulations.

The vivid communicative character of the psalm is achieved by means of several metaphors, images and overt Old Testament themes. In 
$3 \mathrm{~b}$ stones rolling from a mountain and coals thrown from a security wall (Ps 21:11; 140:10; 2 Sam 15:4) are visualised; 5b refers to the heart, locus of several aspects of man's life in the Old Testament; in 6 the wearing of a garment is assumed (Ezek 7:18); 7 contains a comparison with a dove (Song of Songs 1:5; Is 38:14); in 8 the desert is mentioned (Jer 9:1); in 9 a raging wind or tempest (Ps 83:16, Am 1:14) and a shelter; in 11, guards (Songs of Songs 3:3) on the city walls (2 Sam 11:24, 2 Ki 18:26; Is 62:6); and in 22 the description includes flattery words, oil and drawn swords all of which form part of the psalm's imagery and pictorial setting. In its context, every image or theme alludes to a definite feeling or life experience, contributing to the semantic structure of the poem.

The traditions and historical elements of Psalm 55 are carefully embedded in relatively vague allusions, patterns of thought and key phrases. However, the terminology does not obscure the material of the Old Testament traditions.

It is possible to identify themes from the Pentateuch, from the primeval history and narratives of the desert wandering. Moreover, terminology with a so-called priestly background reflects the cultic and priestly influence on the psalm. A motive from the Zion tradition is also perceptible, while prophetic language is present in the legal concepts and themes which express justice or guilt. Although Psalm 55 is not a wisdom psalm, its relationship to wisdom literature is evident.

\subsection{Motives from the Pentateuch}

In the second stanza, a prayer for the destruction of the enemy (10-16), the terminology (10a, "swallow up") and (16, "let them go down lively to Sheol") allude to the fate of Korah, Dothan and Abiram". With this history in mind, the psalmist's prayer urges God to bring the severity and reality of his judgment to bear on his enemy. Like stanza B, which is concerned with the theme of this traditionsgeschichtliche inclusion, the text visualises the grip in which the enemies should be held up. They should be crushed in God's judging hands with no outcome envisaged. In addition, the phrase פלג לעי (10a, "divide their tongue") is reminiscent of the outcome in the Tower of Babel narrative ${ }^{12}$. God's judgment on the people of Babel for their deeds of hubris against him, was to divide their tongues. This punishment devastated their initial intentions, namely to make a name for themselves and not to be scattered across the earth. The psalmist simultaneously asks for God's devastating intervention. Both these elements which are based on the tradition-history of the 
Pentateuch serve to:

- stress God's power in this distressful situation and to emphasise the effect of the divine judgment on the psalmist's enemy; and

- to bring about God's visible ${ }^{13}$, sudden and surprising ${ }^{14}$ judgment on the unjust deeds of the enemy.

\subsection{Cultic and priestly themes}

Like several other psalms, Psalm 55 reflects clear signs of a cultic and priestly Bearbeitung or influence. This becomes particularly apparent in verses 2-3, 10, 14-16, 21-22 and 23. The introductory call to God for help (2-3) presupposes a cultic Sitz im Leben. The prayerful atmosphere, characterised by petitions, wishes and descriptions in 2-3,10a,16,17-18 further presuppose a cultic space in which the "I" can express himself before God. This means that the psalm had fulfilled a definite role in the Israelite cultic life.

The influence of the priestly text, Numbers 16 , on verses 10 and 16 has already been indicated. The occurence of כערכי (14, "my equal") in other cultic texts ${ }^{15}$, probably influenced Duhm and others to describe the former (unfaithful) friend as "ein Priester oder Beamter des Tempels", while Deissler opted for a "schwerent-täuschter Leviten" 16 .

Verse 15 also contains terminology which infers the temple or the

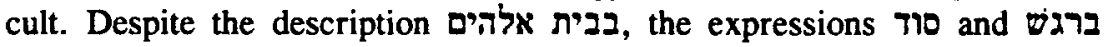
both refer to cultic activities.

T1O is primarily a relationship term and gives expression to a space or sphere in which believers experience God and their communion of faith. This provides for a cultic gathering, with 710 being both an indication of a bilateral relationship ${ }^{17}$, and the communion of the psalmist and his former friend with God in the cult.

Although the meaning of ברג and the qualification בבית אלהים is sufficient reason to relate it to the cult. ברג probably expresses the bustle and restlessness of participants in the feast procession ${ }^{19}$ in the front court of the temple or around the altar ${ }^{20}$. It was there that the psalmist and his former friend had their experience of communion with God. This relationship has been destroyed by the unfaithfulness of the friend.

Exegetes also differ on the precise meaning of aberis in verses 19 and 21 . As a result of the association between this concept and the priestly blessing (Num 6:24-26), it is closely associated with the cult. Even if

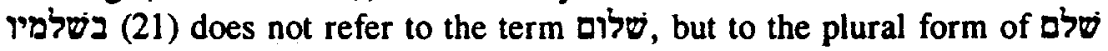


("peace offerings"), it encomes the categories of cultic language. This then forms part of an "Opferterminus" which "auf die einzelnen dargebrachten Opferstücke Bezug nummt" 22.

When the synthetical parallelism in verse 21 is considered, the

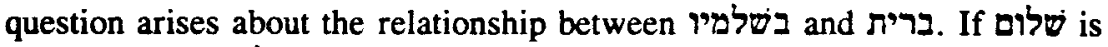
reflected in בשלמיi (21), it may be assumed that the relationship between ברום and was commonplace in the priestly tradition. Several examples in the Old Testament (Num 25:12; Is 54:7-10; Ezek 34:25; 37:26) confirm this assumption.

The phrase היל בל ברית (21) also reflects a formulation used by cultic priests. The priestly background of Malachi 2:10 and Psalm 89:35 confirms furthermore that the desecration of a berit (חלל בריתו) does appear in the sphere of cultic language. In Malachi 2:10 God's berit with Levi $^{23}$ forms the background for the description of the unfaithfulness of Judah and his priests in their berit with Yahweh. According to Malachi 2:5 berit means (" meaning in Psalm 55. God is portrayed as the Provider of life and peace, because he gives big (19) to the righteous in a supposed berit relationship, but he can also take "חי" ("life") away (verses 16 and 24), is desecrated if a berit (21). Psalm 89:35-36 underscores the fact that the breaking of an oath is directly related to the profanation of a berit ${ }^{24}$. Both these relatively late texts therefore confirm that the combination ברית and חל has a background involving cultic priests. A final term that is related to the cult is שמן (22). The content of Psalms 89:21 and 133:2 confirm this relationship.

The view of several exegetes that verse 23 may be a promise of salvation, uttered by a priest or cultic prophet, appears to be borne out by the psalm's relationship to the cult or the psalmist's familiarity with the cultic language ${ }^{25}$. The abundance of cultic and priestly allusions in Psalm 55 confirm the assumption that the text and/or author(s) of this psalm were closely associated with the cult. It could have been prominent in priestly circles and could even be an indication of the late date of the text.

\subsection{Allusion to the Zion tradition}

A comparison with other Old Testament texts can contribute to the identification of a theme from the Zion tradition. ישב וישב is a Sonderformulierung in Psalm $55^{26}$ expressing a divine action. The verb 20 , refers to the act of ruling and is applied in the Old Testament to Yahweh's role as judge ${ }^{27}$ and king $^{28}$. קד on the other hand is a chiffre for time ${ }^{29}$ and 
space $^{30}$. A text such as that of Deuteronomy 33:27 makes it clear that Yahweh is the God of קדם. With this title in mind, his power and reign over the enemy are emphasised in the psalm. קרם (20a) thus becomes the chiffre for unknown time and space categories. God, who has heard the psalmist's plea (18b-19), will overwhelm the enemy with his ruling power while listening to them $(20 \mathrm{a})$.

The above-mentioned interpretation of מיטב the majority viewpoint ${ }^{31}$ which interprets the text as מקדם ("from old"). In my view the use of טקדם would restrict the potential meaning of the text or the author's intention and would limit the meaning to an indication of time only. Moreover, if this interpretation is accepted, it would be a violation of the psalmist's characteristic style which presents the semantic content in several time and spatial categories. The Zion theme ultimately functions to:

- emphasise God's unlimited power as judge and king over the enemy;

- strengthen the faith of "I" that God who delivers the righteous, will strike the wicked with all his power; and

- express the greatness of God's power in hymnic form.

\subsection{Prophetic language}

Prophetic language in the psalm is identifiable by means of the legal concepts and themes as well as terminology which expresses justice or guilt. Other themes that have a prophetical overtone are also evident.

Specific similarities between the text and themes or language from Jeremiah, particularly Jeremiah 9:1 ff, have been identified by exegetes ${ }^{32}$. In Psalm 55 the psalmist, like Jeremiah, expresses the desire to flee into the desert in order to express his loneliness, fear and search for a safe shelter. For the present purpose it is not important to determine the extent of the dependence of the one text on the other or to trace a common source which could have influenced both the psalm and Jeremiah's text ${ }^{33}$. Such a comparison merely reveals that the psalm reflects prophetic language. It is therefore important to determine separately the function of every theme in the various texts of Jeremiah and of the psalm. Further similarities with themes in Ezekiel $7^{34}$ and Habakkuk ${ }^{35}$ are also noticeable.

Prophetic texts often contain the theme of the endangered city $(10)^{36}$ and the image of the dove (7). Exegetes differ on the meaning of the image of the dove ${ }^{37}$, but related terminology such as (7, "wings"), אעופה (7, "I will fly") and (9, "I will haste") strengthen the argument that this image visualises the supplicant's desire for a quick release from the danger. 
Deissler's ${ }^{38}$ association of the theme of a "treacherous friend" with the same theme in Micah 7:1-15 is speculative. Although the text of Micah contains themes that are similar to those in Psalm 5539, it should be noted that the theme of a "treacherous friend" appears throughout the Old Testament ${ }^{40}$. The author of Psalm 55 could have used this theme in his text independent of the author(s) of Micah. The text is not necessarily dependent on Micah 7.

The psalm's relationship to prophetic language is illustrated by the valence of legal concepts and terminology which express guilt. Research has revealed that the concept oמn (10b, "violence") has its roots in the legal traditions of the Old Testament. It expresses any unlawful act in a community and can therefore be defined as "die Verletzung der Pflicht gegen den Nächsten" or "die Einschränkung seines Lebenrechtes und Raumes" 42 .

Verse 22 confirms that חמס (10) and

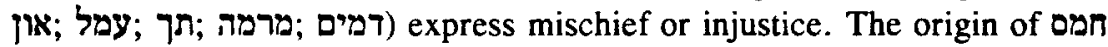
is not necessarily physical violence, but also includes the product of the mouth or the tongue. Psalm 140:12 states that a " violence") is a ("man of the tongue"). As a comprehensive term, pמ expresses the highest guilt that someone can have in respect of another person. This corresponds to the content of Psalm 55, in which the om and other related deeds of the enemy force the distressed psalmist to seek justice from God's hands (17). By means of a hendiadys, on is combined with the term Prozeßrechts" 44 . The subsequent high incidence of legal concepts in verses 11 to verse 24 leads to a climax in the description of the injustices committed against the psalmist.

The word pair און וצמל appears in 11b/12. און can be interpreted to be a "unheilvoller Aktivität" which manifests itself in different forms ${ }^{45}$, while עמל can be summarized in general terms as "das böse, lügnerische und gewalttätige Handeln der Feinde" ${ }^{46}$. According to the descriptions conformed in verses $4-5,10-15$ and $20-22$, this was exactly what the psalmist experienced. הוות (11b/12), a well-known Old Testament description of mischief ${ }^{7}$, adds to this evil behaviour. The term מרמה forms a hendiadys with both ת (12b) and (24b). These unlawful deeds are rooted in the heart $(22)$ and are expressed by the mouth $(10,12)$. In $7 \pi$, the dishonesty or "Falschheit" 48 of the enemy is expressed, while דמים (24b) probably expresses the highest form of guilt in respect of the psalmist. An offence committed against the latter (13-15), becomes an offence committed against God (20b). This highest form of guilt is expressed in the term דמים (24b). 
The high incidence of legal terms and their expression in word pairs therefore fulfil the functions:

- to build tension in the "I" versus enemy relationship up to a climax in verses $13-15,16$ and $24 b$; and

- to emphasise in qualitative and quantitive terms the injustice committed by the enemy in respect of the psalmist.

\subsection{Wisdom motive}

Psalm 55 is not a wisdom psalm. Nevertheless the text which reveals the relationship between the צדיק $(23)$ and the $(4,24)$ and this relationship with God, reflects sapiential thoughts. Verses 23-24 draw a conclusion regarding these relations: Yahweh cares for the righteous, but the wicked can be assured of his destruction (24a באר שחת ) and the diminution of life (24b). The basic trend of the principle of retribution - in which the righteous is blessed and the wicked punished by God - is embedded in this conclusive thought. It gives the psalmist his final hope before he ultimately utters his confession of trust (24c). The impression that the text may alludes to wisdom language, is strengthened by the fact that the psalm also has common ground with the vocabulary and themes that appear in Job49 and Proverbs ${ }^{50}$. Similar expressions and terminology appears in both texts.

There are few obvious similarities between the psalm and the most recent of the Old Testament books. Besides the similarities with the book of Job, there are also a few examples of common language with the books of Zechariah ${ }^{51}$ and Daniel ${ }^{52}$. However, these examples do not establish clear ties between Zechariah and Daniel on the one hand and Psalm 55 on the other. They rather reflect an atmosphere which could have influenced the author(s) or of which he could have been aware of.

The use of language, motives or allusions from wisdom literature and most recent books of the Old Testament, does not prove the psalm's dependence on these texts, but rather strengthens the perception or assumption that the Endgestalt of Psalm 55 indicates a relatively late postexilic date.

\section{CONCLUSION}

In conclusion, several tradition-historical motives, images and allusions of the Old Testament can be identified in Psalm 55. Each of them fulfills a specific function in the text. Themes from the primeval history and period 
of wandering, the spheres of cultic priests, a theme from the Zion tradition, prophetic language and single sapiential allusions all contribute to an understanding of Psalm 55.

\section{NOTES:}

1 R Kittel, Die Psalmen ubersetzł und erklär, Leipzig ' $1929,199$.

2 H C Leupold, The Psalms, London 1959, 421; J H Eaton, Psalms, London 1967, 146; M Dahood, Psalms II (Anchor Bible), New York 1968, 30; H Gunkel, Die Psalmen, Göttingen 51968, 237; A A Anderson, The Book of Psalms (Vol 1), London 1972, 412; J P M van der Ploeg, Psalmen, Roermond 1973, 333; N A van Uchelen, Psalmen deel II: 41-80, Nijkerk 1977, 108; J Krašovec, Antithetic structure in biblical hebrew poetry, Leiden 1984, 68.

3 J Ridderbos, De Psalmen, Kampen 1958, 110.

$4 \quad$ M E Tate, Psalms 51 -100, Dallas 1990, 55.

$5 \quad$ H Schmidt, Die Psalmen, Tübingen 1934, 107.

6 E S Gerstenberger, Psalms, Part I. With an introduction to cultic poetry (FOTL 14), Grand Rapids 1988, 226.

7. Kittel, op cit, 1929, 199.

8 F Baethgen, Die Psalmen, Göttingen 1904, 159; C Westermann, "Struktur und Geschichte der Klage im Alten Testament", Zeitschrift für die alttestamentliche Wissenschaft 66 (1954), 48.

9 This was done in a paper delivered at the SBL congress in Dublin (1966) by me with the title "Psalm 55: some reflections on its compositional understanding". It will soon be published.

10 See previous footnote.

11 See Numbers 16:30-33. C A \& E G Briggs, $A$ critical and exegetical commentary on the book of Psalms, Edinburgh 1907, 21; Leupold, op cit, 423; A Weiser, The Psalms, London 1962, 420; Eaton, op cit, 147, etc; the tradition also occurs in Proverbs 1:12 and Isaiah 5:14. See further Psalm 21:10 and Isaiah 19:3.

12 See Genesis 10:25 and 11:9. Briggs \& Briggs, op cit, 21; A F Kirkpatrick, The book of Psalms, Cambridge 1921. 310; Kittel, op cit, 199; Ridderbos, op cit, 113; Leupold, op cit, 423; E J Kisane, The book of Psalms, Dublin 1966, 240; Eaton, op cit, 146; Anderson, op cit, 414; J W Rogerson \& J W McKay, Psalms 51-100 (Cambridge Bible Commentary), Cambridge 1977, 32 and Tate, op cit, 57.

13 Kirkpatrick, op cit, 312.

14 Baethgen, op cit, 162; Weiser, op cit, 420; Anderson, op cit, 416; Rogerson \& McKay, op cit, 33; Tate, op cit, 57.

15 See Leviticus 5:15, 18, 25; 27:2, 8, 12-13, 15, 17-18, 23, 27; Numbers 18:16; 2 Kings 12:5 (23:35).

16 B Duhm, Die Psalmen, Tübingen 1899, 151; W O E Oesterley, The Psalms Translated with text critical and exegetical notes (Vol 1), New York 1939, 285; A Deissler, Die Psalmen, Düsseldorf 1964. 219. Also M Goulder, The prayers of David, Sheffield 1990, 24, is of the opinion that the author was a priest or a cour poet. 
17 M Sæbф, "sod Geheimnis", in: E Jenni \& C Westermann (eds), THAT II, München 1984, 147; H J Fabry, "sôd", in: G J Botterweck \& H Ringgren (Hrsg), TDOT V, Grand Rapids 1986, 779.

18 See Psalms 2:1 and 64:3. Both references give expression to a kind of "bustle" or "restlessness".

19 Baethgen, op cit, 162; Kirkpatrick, op cit, 312; F M Th Böhl, De Psalmen 1 (Tekst en Uitleg), Groningen 1968, 95. See Psalm 42:5.

20 Ridderbos, op cil, 113.

21 G Gerleman, “ $y l m$-genug haben”, in: E Jenni \& C Westermann (Hrsg), THAT II (1984), 922ff, says that סלום not only means "peace", but "Vergeltung" in a positive (Genugtung, Genüge) and a negative (Bestrafung, Rache, Ahndung) sense.

22 G von Rad, Old Testament Theology, Vol 2. (Transl. I G M Stalker), London 1975,257 is also of the opinion that it refers to the "fat parts of the slaughtered animal".

23 See also Deuteronomy 33:8-9: For Levi, this berit means "life" (חי"ם) and "peace" (שלום). In Psalm 55 God is also seen as the Provider of a" $\Pi$ (16) and (19). He can therefore grant it, like in verse 19, or take it away, like in verses 16 and 24 .

24 Ridderbos, op cit, 115, proves from 1 Samuel 20:16, 42; 23:18 and Ezekiel 16:58 that $ל$ n supposes a commitment by oathtaking. Tate, op cit, 58, confirms it.

25 Deissler, op cit, 219; Gunkel, op cit, 238; Anderson, op cit, 419; Rogerson \& McKay, op cit, 36; H J Kraus, Psalmen (BKAT XV/1), 1-59, Neukirchen $1978,405$.

26 Jonah 4:5 has the nearest parallel of the consonant text, namely ויסב מקרם.

27 See Psalm 9:5, 8, 12. As a Zion motive, see further Micah 4:3.

28 See Psalms 2:4; 29:10; Isaiah 6:1, 4. As a Zion motive, see further Micah 4:7.

29 An indefinite time period is normally indicated by 07 , mostly with the prefix To. See Psalms 74:12; 77:12; Hab 1:12.

30 The term then indicates the "east" or "unbekannte Ferne" - see Genesis 2:8; $11: 2$; Judges $6: 13$, etc. C Westermann, "The role of the lament in the theology of the Old Testament", JBL 28 (1974), 287.

31 Baethgen, op cit, 163; Briggs \& Briggs, op cit, 26; Kirkpatrick, op cit, 313; Oesterley, op cit, 284; Ridderbos, op cit, 114; Weiser, op cit, 419; Van Uchelen, op cir, 104; Tate, op cit, 52.

32 Weiser, op cit, 419; Deissler, op cit, 219 and Dahood, op cit, 33.

33 Dahood, op cit, 30,32, is convinced that a common source was used by both authors of Psalm 55 and Jeremiah 9.

34 Compare Ezekiel 7:11, 23 with Psalm 55:10b; 7:15, 23 with 55:10b; 7:16 with $55: 7 ; 7: 18$ with $55: 6 ; 7: 22$ with $55: 21 ; 7: 23$ with $55: 24$ and $7: 25$ with 55:19,21.

35 Compare Habakkuk $1: 2,3$, 9 with Psalm 55:10b; $1: 3$ with $55: 10 \mathrm{~b}, 11 \mathrm{~b} ; 1: 4$ with $55: 4,23$ b as well as $3: 19$ with $55: 1$.

36 Isaiah 29:15, 20-21; Jeremiah 6:3-7; Ezekiel 7:23; Amos 3:6; Zephaniah 3:1; Zechariah 14:4.

37 Several exegetes interpret the function differently. The dove is for example seen as symbol of innocence, senselessness, fear, security, beauty and speed. 
38 Deissler, op cit, 219.

39 Compare the motives in Micah 7:2 with Psalm 55:24b; 7:5 with 55:4 and 7:5 with 55:22.

402 Samuel 16:15ff; 17:14ff; Jeremiah 9:5; 20:9; Job 6:15; 19:19; Psalms 31:12; 38:12; 41:10; Proverbs 2:17; 16:28; 17:9.

41 See R Knierim, Studien zur israelitischen Rechts- und Kultgeschichte, Heidelberg 1957, 125; H J Stoebe, "סטח-Gewalttat", in: E Jenni \& C Westermann (Hrsg), THAT I, München 1984, 585 and H Haag, "obn-chamas", in: G J Botterweck \& H Ringgren (eds), TDOT IV, Grand Rapids 1980, 482.

42 Stoebe, op cit, 586.

43 Haag, op cit, 482. Compare Genesis 16:5; Proverbs 10:6 and 16:29.

44 G Liedke, "ביר-streiten", in: E Jenni \& C Westermann (Hrsg), THAT ll, München 1984, 722.

45 Knierim, op cit, 84. See Isaiah 32:6 and Psalm 66:18.

46 S Schwertner "עמל-amal. Mühsal", in: E Jenni \& C Westermann (Hrsg), op cit, 1984, 332.

47 Psalms 5:10; 38:10; 52:4,9; 57:2; 91:3; 94:20; Job 6:2,30; 30:13; Proverbs 17:4 and 19:13.

48 F D Hubmann, “Textgraphik und Textkritik am Beispiel von Jeremia 17, 1-2”, Biblische Notizen 14 (1981), 33.

49 Compare Psalm 55:2 with Job $33: 1 ; 34: 16 ; 37: 14 ; 55: 2$ with $6: 16 ; 55: 3$ with $7: 13$; 55:4 with $16: 9 ; 30: 21$; $55: 5$ with $9: 34 ; 13: 21 ; 20: 25 ; 33: 7 ; 39: 20 ; 41: 6$; $55: 10$ with $38: 25 ; 55: 10$ with $2: 3 ; 8: 18 ; 10: 8 ; 55: 15$ with $20: 12 ; 21: 33 ; 24: 20$. $55: 16$ with $21: 13$; $55: 19,22$ with $38: 23$; $55: 20$ with $10: 17 ; 14: 14$; and $55: 22$ with $20: 17 ; 29: 6$.

50 Compare Psalm 55:3 with Proverbs 23:29; 55:10 with 19:28; 21:20; 55:14 with $2: 17 ; 16: 28 ; 17: 9 ; 55: 22$ with $5: 3 ; 55: 22$ with $30: 33$; and $55: 23$ with $18: 14$.

51 Compare Psalm 55:19, 2 with Zechariah 14:3; and 55:23 with 11:16.

52 Compare Psalm 55:12, 24 with Daniel 8:25; 11:23; 55:21 with 11:42; 55:18 with $6: 11,14$ and $55: 4$ with 9:25. 